\title{
Agricultural production and food consumption of mountain farmers in Tanzania: a case study of Kiboguwa village in Uluguru Mountains
}

\author{
Yuko Yamane ${ }^{*}$ (D), Jagath Kularatne and Kasumi Ito
}

\begin{abstract}
Background: The present study investigates the agricultural practices and food security of rural areas in Africa by observing the farming and food consumption patterns in Kiboguwa village, on the eastern slopes of the Uluguru Mountains, Tanzania.

Results: The participant observation method was employed to collect and analyze the data of four village divisions: Kiseneke, Changa, Ludewa, and Mungi. Empirical research was conducted on the agricultural and food consumption patterns of the villagers using firsthand information. The production of two main types of cereals, maize and rice, was insufficient owing to low productivity or low production. Many households sell bananas grown in home gardens to compensate for cereal food shortages. Therefore, as a commercial crop, bananas play a vital role in achieving food security for the villagers.
\end{abstract}

Conclusion: The present study demonstrates the importance of different dimensions of agriculture and staple food crop productivity. It also describes the specific situation of rural farming in Africa. The newly collected information could help policymakers enhance food security in the areas under investigation.

Keywords: Commercial crop, Mountain agriculture, Rural Africa, Home garden, Food security, Staple food crops

\section{Background}

In developing countries, agriculture is based on highly connected technical systems and a food culture that nurtures the inhabitants over an extended period. Therefore, the details and methods of agricultural and rural development projects, as well as the purpose of research on tropical agriculture, must be relevant to actual situations [1]. However, the flow of information is generally from top to bottom, arising from researchers and technologies that rely on specialized fields of modern agriculture, such as agronomy or crop breeding [2]. Modern agriculture is a science based on a philosophy that aims to improve agricultural productivities and improve farm

*Correspondence: yamane@agr.nagoya-u.ac.jp

International Corporation Center for Agricultural Education, Nagoya University, Nagoya-shi, Chikusa-ku, Furocho 464-8601, Japan management [3]. This phenomenon took place in developed countries during the process of industrialization, and recently, agricultural development is generally measured by using productivity and efficiency per land or per time [3]. In Africa, various staple food patterns and crop cultivation methods can be observed across ethnic groups and regions, and within countries. According to the data of FAO Stat, the productivity of main staple food crops, such as rice and maize, per area in Africa has not been increased significantly since the 1960s even though many agricultural projects have been conducted in Africa also like Southeast Asia. Therefore, it can be said that agricultural supports did not help to improve crop productivity in Africa much [4].

Tanzania, located in East Africa, is classified among the least developed countries, with approximately $80 \%$ of the population engaged in growing food in rural areas for 
their consumption. The differences in staple food crops of the rural population are closely related to the differences in their agricultural practices and crop cultivation. A variety of agricultural systems exists in food production. Staple food crop cultivation practices, in particular, vary significantly depending on the ethnic groups and regions in Tanzania. This agricultural diversity has evolved and matured under the local environment and culture.

Recently, many regions in Tanzania have been adversely affected by land shortages and degradation of the soil due to an increasing population [5-7]. Therefore, solutions are needed to cater to the needs of this growth. Detailed knowledge about the behavior of individuals or the specific situations associated with rural agricultural systems is necessary to provide appropriate support [8]. Recent research in agriculture in Tanzania has many researches such as themes dealing with agricultural influences of environmental fluctuations [9], and studies based on empirical and detailed surveys are very limited, such as Yamane and Higuchi (2016) [10]. While there are suggestions for agricultural support policies, there are few attempts to gain a deep understanding of the realities of local agriculture only based on concepts [11] and research based on social surveys [12]. Therefore, information to understand the actual situations of rural agriculture in Africa, including Tanzania, is limited since there are few studies on it.

The people of Kiboguwa village, located on the eastern slopes of the Uluguru Mountains (Fig. 1a), produce their food in both cultivated lands and home gardens distributed along the slopes of the mountains. The villagers have achieved self-sufficiency, as they cultivate different types of staple food crops, such as cereals, bananas, and various kinds of potatoes. However, the diet of the villagers and the agricultural mechanisms in place to ensure adequate nutrition have not yet been investigated. Therefore, the present study examined the relationships between staple foods and their cultivation in Kiboguwa village. More specifically, this study aimed to determine the farming systems by which the farmers of Kiboguwa village secure their food supply. Therefore, the results of the present study could assist policymakers in providing the required support to the local population, taking into the consideration of the specific situation of rural development in Africa.

\section{The study area}

The population of the study area, Kiboguwa village, was 1402 in the 2002 census. According to the 1988 census, the population of Morogoro region was 225,857. In 2002, it was 263,012 , and in 2012 , it was 286,248 . The annual rate of population increase from 1988 to 2002 was $1.17 \%$, whereas from 2002 to 2012 reached $0.88 \%$, indicating that the population hardly increased. Therefore, a dramatic increase in the number of village households due to population increase might not have occurred during the time of the survey period (2004 to 2007), and afterward till 2013 (Data source: http://www.nbs.go.tz/). Kiboguwa
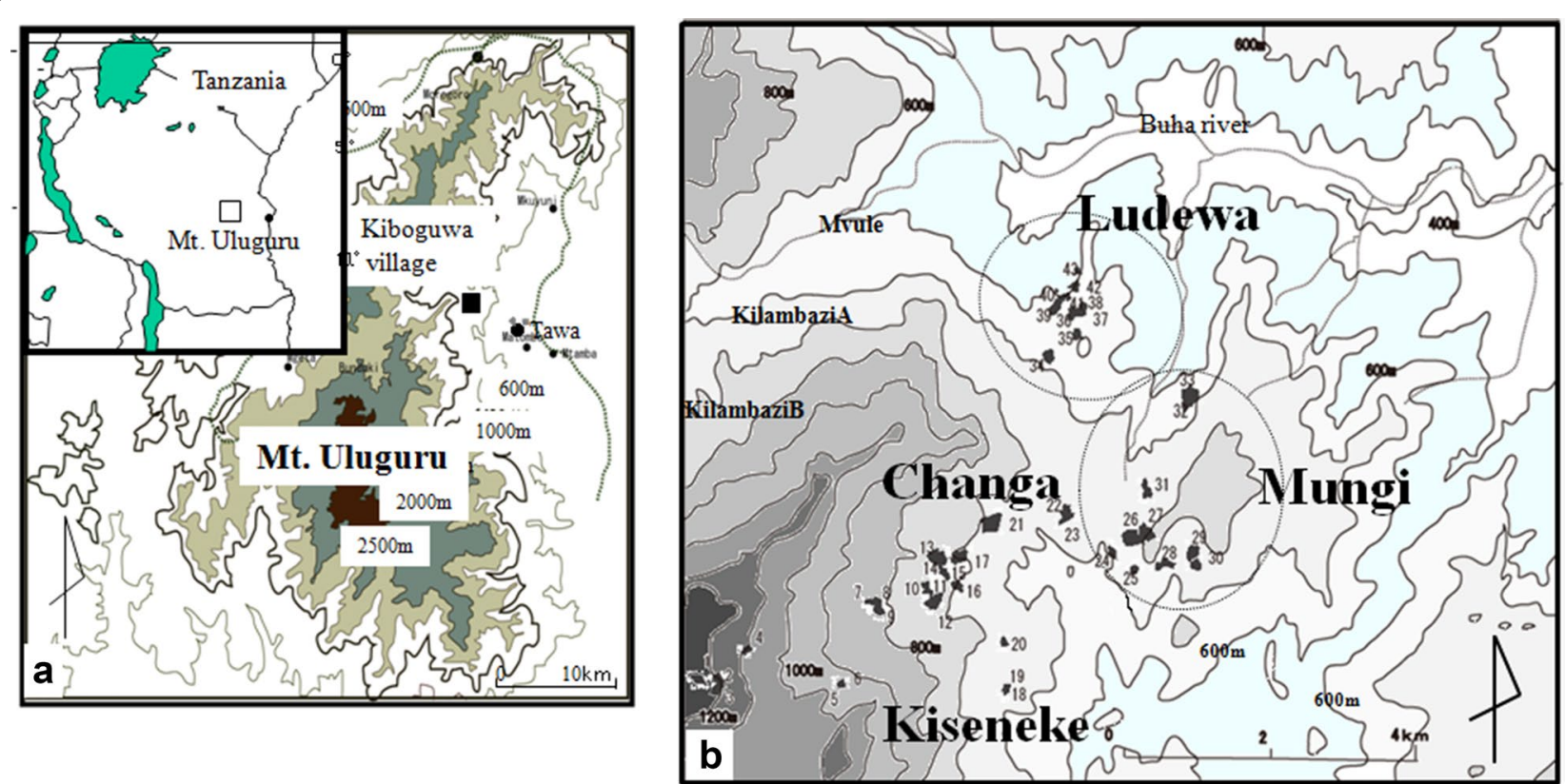

Fig. 1 Location Maps of the Uluguru Mountain and Kiboguwa village. a Location of the Kiboguwa village in the Uluguru Mountain. b Topographic map of the Kiboguwa village 
village has seven divisions (Kitongoji, in the Swahili language) that cover the slopes of the ridge running through the center of the village at elevations of 800 to $1400 \mathrm{~m}$, as well as the valleys. The greatest difference in elevation is in the Kiseneke village division. At the eastern end of this ridge is a cliff. The Changa village division, located in the middle of Kiboguwa village, has the highest number of households and is considered the village center. It extends across the slope at the foot of the aforementioned cliff. Nvule, Ludewa, and Mungi village divisions are located toward the northern part of the Changa village division.

Two types of land use patterns were observed in Kiboguwa village (E: $37^{\circ} 40^{\prime} 50-37^{\circ} 42^{\prime} 20$, S: $\left.6^{\circ} 59-7^{\circ} 00^{\prime} 35\right)$, namely cultivated lands (primarily) and home gardens. The cultivated lands (Kumugunda, in the Luguru language) are used for the cultivation of staple food crops, such as maize, rice, and cassava. Soil is classified as Lixisol or Acrisol according to the FAO/Unesco method [13]; because weathering is progressing, it is not overwhelmed by nutrient retention capacity. The estimated rainfall is $1200 \mathrm{~mm}$ /year on the eastern slope of the mountain [14]. The mean annual temperature is about $24.3^{\circ} \mathrm{C}$ with a maximum of $26.5^{\circ} \mathrm{C}$ in December and a minimum of $21.1^{\circ} \mathrm{C}$ in July. The mean annual temperature was $19.5^{\circ} \mathrm{C}$ with a maximum of $22^{\circ} \mathrm{C}$ December and a minimum of $17{ }^{\circ} \mathrm{C}$ July [15]. According to the customary land tenure system of these people, male and female clan members have equal usufructuary rights from birth to death to cultivate the clan's land [16]. However, individuals are not recognized as owners of the land, and they did not have the property right. Conversely, the ownership rights for perennial crops that last for many years, such as tree crops, belong to the person who planted them. This scenario creates the possibility of inheritance of the perennial crops as the property of children who are not members of the land's clan. Therefore, people with usufructuary rights for the land owned by their clan may differ from the owners of tree crops planted on that land. Thus, under the original land tenure system, tree crops and other perennial crops are recognized as difficult crops to plant on the clan's land due to the need to obtain first the consent of the clan members [16]. Nonetheless, at present, many tree crops forming a thick forest landscape are noted in the home gardens from study region, but growing tree crops, i.e., perennial crops, are difficult to find on clan land [17]. The only livestock that the people kept in this village is the goat. However, due to lack of grasslands for grazing, it was less than five or few goats. They are distributed from the lowest altitude, about $600 \mathrm{~m}$ above sea level, to the top, at approximately $1400 \mathrm{~m}$ along the slopes. Almost all of the land, including the steep slopes, has been used for cultivation. The home gardens are referred to as Ditzulala in the local language. Many types of crops are intensively grown in the Ditzulala, such as cinnamon (Cinnamomum zeylanicum), pepper (Piper nigrum), and cardamom (Elettaria cardamomum), and tree crops, such as breadfruit (Treculia Africana, Artocarpus altilis), coconut (Cocos nucifera), and coffee (Coffea arabica/C. robusta). A thick forest landscape has been created around the houses of the village owing to the aforementioned crop cultivation. The villagers also plant herbaceous crops, including banana (Musa spp.), corn (Zea mays), and the common bean (Phaseolus vulgaris). The cultivation of banana has been observed in most home gardens of the village [10]. On the other hand, tree crops or perennial crops (including banana) are rare on the Kumugunda.

\section{Methods}

The participant observation method was employed to decide what kind of data we needed to explain the relationship between cultivation and food and how to collect them. It is done through an experimental survey in the study village, as this is a popular method used in anthropological studies [18]. Methods of data collection and analysis of specific information are shown below. The author (Yamane) resided in the Kiboguwa village for a total of one year as follows: three months from July to October 2004; four months from June to September 2005; one month in December 2005; two months from December 2006 to January 2007; and two months from June to July 2008. The author stayed mostly at the homes of the farmers, observing their ways of life, such as their food consumption and agricultural patterns, and those of the villagers. The information was gathered from four village divisions: Kiseneke, Changa, Ludewa, and Mungi. The author identified 254 households among the four divisions. The present study covered $74 \%$ of the total population of the village. Data collection was focused mainly on two aspects: the daily meals of the villagers and the cultivated staple food. The author visited the study village in Dec 2017 again, and it was confirmed that the agricultural landscape had not changed drastically. Specific data collection and analysis methods are shown below.

\section{Daily meals of the villagers}

Four farmers were randomly selected from four village divisions: Kiseneke, Changa Mungi, and Ludewa. The farmers were asked to record details of daily meals, such as crop types and cooking type, for the period between 2004 and 2005. Daily meals consumed within the study area typically consist of a main dish of staple food and side dishes. The staple foods include principally starch crops, cereals, and root crops, whereas the side dishes usually comprise vegetables or beans. The villagers had purchased small fish as a protein source, but the meat 
they consumed were the chickens or goats, and the meat had been consumed only a limited number of times per year. Consumption of every staple food crop was assessed. Inhabitants of Kiboguwa village typically have three meals a day. Thus, if maize was consumed for all three meals, the consumption number for maize in a day would be three. If multiple staple food crops were consumed during a meal, the consumption number was then divided by the number of each type of crop.

The final consumption (expressed as a percentage) of each staple food crop was calculated to be proportional to the overall consumption of food. For example, if taro (Colocasia esculenta) and yam (Dioscorea alata) were consumed in equal amounts during a meal, the consumption number of yam and taro would be 0.5 each.

\section{Cultivated staple food crops}

A survey questionnaire was carried out in September 2005 among 43 randomly selected households in the four divisions of Kiboguwa village, to gather information about staple food crop cultivation. The number of households surveyed in the village divisions of Kiseneke, Changa, Mungi, and Ludewa was 23, 3, 10, and 10, respectively. Information about the size (area) of the cultivated fields of maize, upland rice, and cassava distributed along the slopes, named locations of the cultivated areas in the village, and cereal production was collected, except production of cassava.

From December 2006 to January 2007, the same survey questionnaire was used for a total of 84 households; specifically $21,23,18$, and 22 households in the village divisions of Kiseneke, Changa, Mungi, and Ludewa, respectively, were surveyed. Some questions were included to obtain information about the consumption of self-grown staple food crops. In 2007, the farmers were asked by what means they were able to obtain their food.
A total of 254 households were identified among the four village divisions, via images captured by the QuickBird satellite sensor on October 04, 2005. The final sample size was 84 households. Therefore, approximately $33 \%$ of the households in the four village divisions were surveyed.

\section{Results}

Characteristics of meals with a focus on staple food Consumption rate of each staple food crop among four households

Figure 2 shows the consumption rate of different types of staple food crops, as reported by four homemakers living in four different village divisions, over one year approximately (2004). Each household consumed a total of ten types of staple food crops. Wheat was not included among the crops cultivated in the villages. The consumption rates of the three crops, maize, rice, and cassava, were higher than those of the other staple food crops.

The three main staple foods accounted for approximately $20 \%$ each of total consumption, and the total consumption rate of these three crops reached nearly $60 \%$ in the four households. Thus, these three grains (maize, rice, and cassava) were considered primary staple food crops.

The consumption rates of the remaining seven staple food crops were approximately or less than 10\%. Among those crops, the four households under investigation consumed banana at a comparatively higher rate; taro and wheat consumption exceeded 10\%; and breadfruit, yam, and sweet potato accounted for less than $5 \%$. Only three households (A, B, and D) consumed sorghum, and the consumption rate for this crop was less than $5 \%$.

\section{Production of staple food crops}

The consumption patterns of staple food crops among the four households exhibited similar patterns, as described

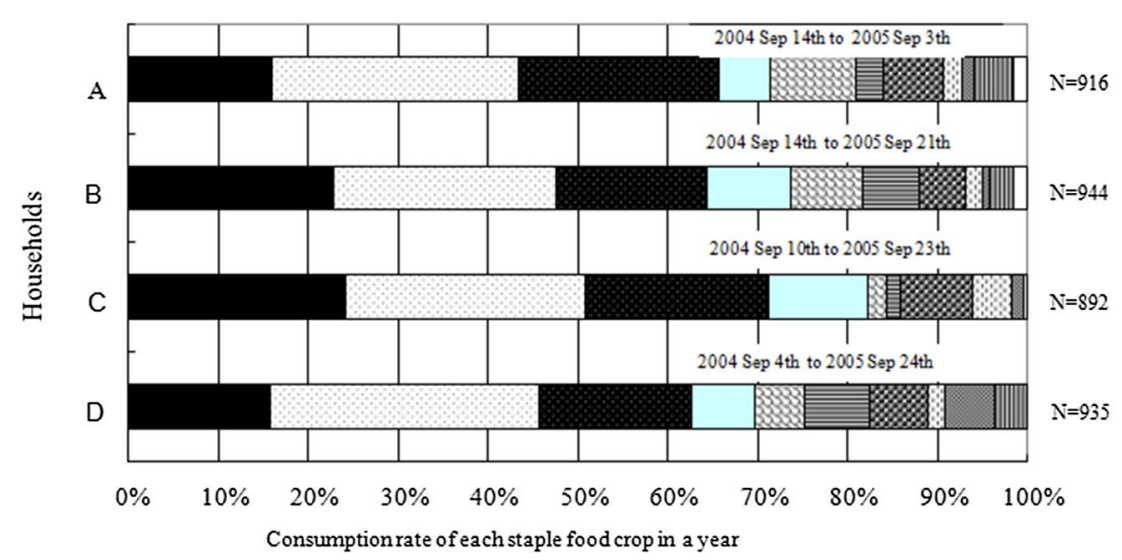

Maize

Cassava

Rice

Banana

Taro

Wheat

Breadfruit

Yam

Sweet potato

Sorghum

Without staple food

Fig. 2 Consumption rate of ten different staple food crops of four households in a year 
in the previous section (Fig. 2). The production of staple food crops (with the exception of wheat) by the farmers in the village can be described as follows.

\section{Distribution of cultivated fields and cultivation of the three main staple food crops}

The lands on the slopes of the village were almost entirely cultivated with three types of staple food: maize, cassava, and rice. Each crop was grown at a suitable altitude during the appropriate season.

The distribution of lands in the village, cultivated by 84 households (2006), is shown in Fig. 3a-c. Upland rice fields were distributed mostly at lower altitudes near the Buha River, whereas other upland rice fields were also located at relatively low altitudes in the Kiseneke village division. Only a few upland rice fields are located in areas $1000 \mathrm{~m}$ above sea level (Fig. 3a). Most of the maize cultivation was distributed approximately $800 \mathrm{~m}$ above sea level (Fig. 3b). The temperature at different altitudes (650, 750 , and $1000 \mathrm{~m}$ above sea level) along the slopes was measured from September 2005 to November 2006. The difference in temperature between an altitude of $1000 \mathrm{~m}$ and that of $650 \mathrm{~m}$ above sea level was $2{ }^{\circ} \mathrm{C}$ during that period (Fig. 4).

Maize is generally cultivated at a higher altitude under cooler environmental conditions than upland rice. Maize cultivation begins from July, when the temperature begins to gradually increase. The maize grain reaches the ripening stage when the temperature approaches the annual peak, and the crop is harvested in December. Therefore, maize was cultivated once a year in this village because it needed about six months for the cultivation.

Upland rice was generally cultivated at a lower altitude, in comparison with the other two main staple food crops. According to the cropping calendar of rice in the village, the slash-and-burn method (Kufeka, in the Luguru language) is implemented in January, when the temperature gradually decreases (Fig. 4). Rice is harvested in June at the lowest temperatures of the year. For rice seedlings, a relatively low temperature (below $18{ }^{\circ} \mathrm{C}$ ) prevents booting [19]. The temperature of the village is generally below $18{ }^{\circ} \mathrm{C}$ at an altitude of $1000 \mathrm{~m}$. The lowest temperature is recorded from June to July, when the minimum temperature is approximately $15^{\circ} \mathrm{C}$, even at an elevation of $750 \mathrm{~m}$. Cold weather presents a hindrance during the ripening

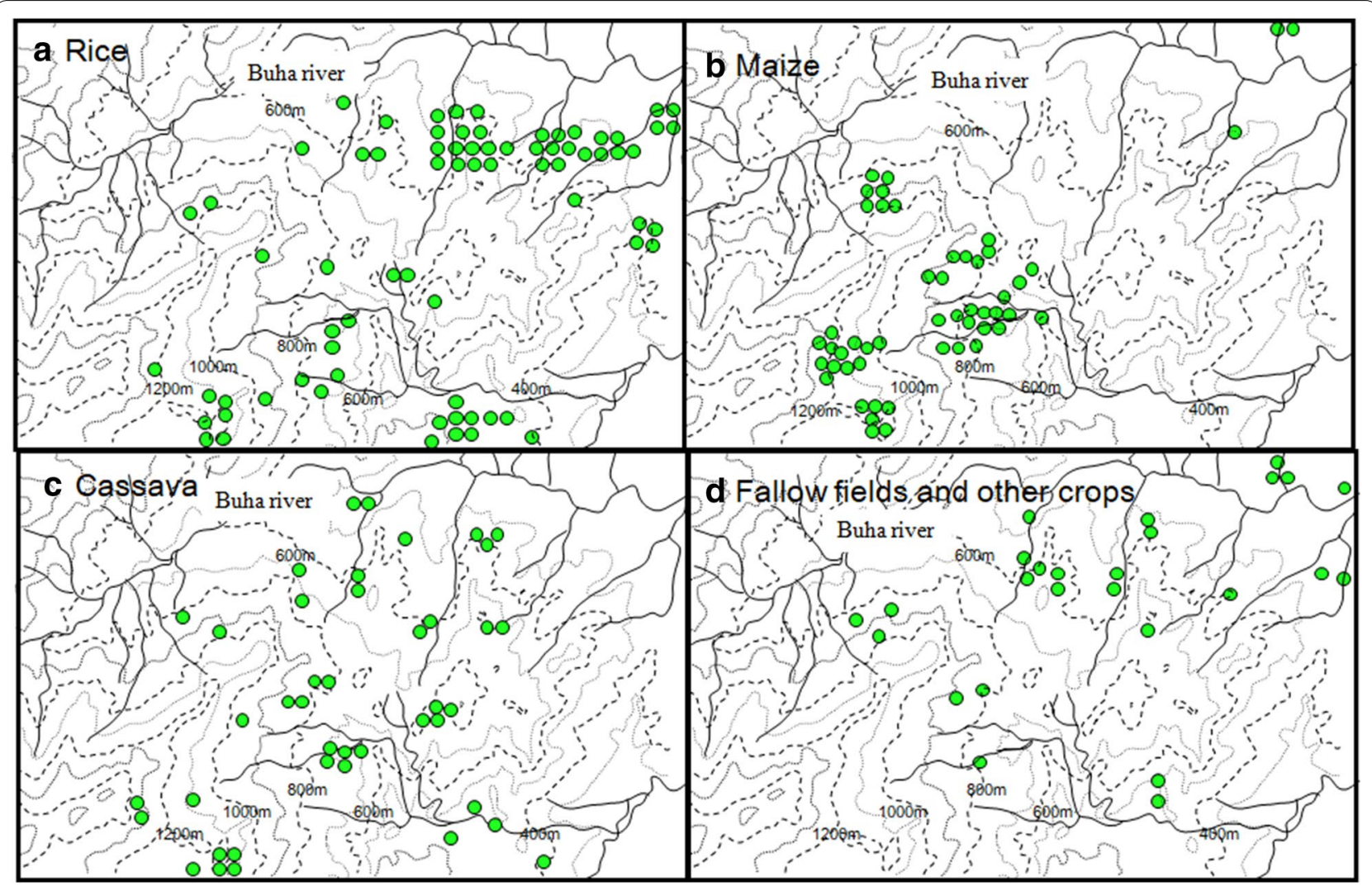

Fig. 3 Distribution of cultivated fields of three main staple food crops on the slopes in the village. a Distribution of cultivated fields of upland rice. b Distribution of cultivated fields of maize. c Distribution of cultivated fields of cassava. $\mathbf{d}$ Distribution of fallow fields and cultivated fields of other crops 


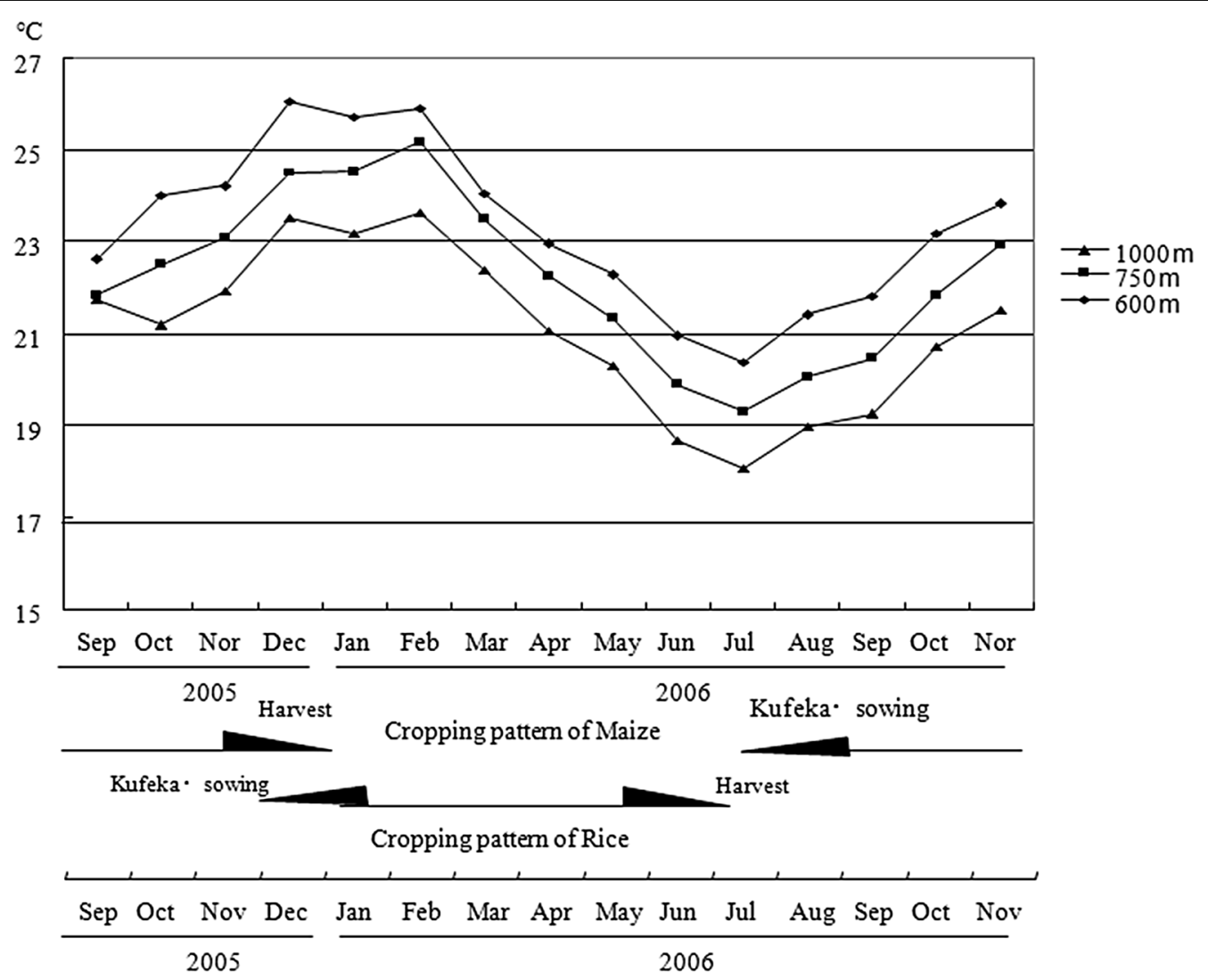

Fig. 4 Cropping calendar of maize and upland rice in the village and annual temperature fluctuation at different altitudes

stage. Therefore, cultivated fields located $1000 \mathrm{~m}$ above sea level are unsuitable for upland rice cultivation.

Lands in the village that were cultivated with cassava were interspersed between the upland rice and maize plantings (Fig. 3c). In addition to the three staple crops, field crops such as cinnamon or fallow lands were distributed along the lower parts of the village, particularly near the Buha River (Fig. 3d).

\section{Consumption and production of staple food crops}

Villagers worked extensively in cultivation of the main staple food crops, and they have spent a considerable amount of time in maize and upland rice farming. The yields of these two crops per household and the calculated land area were analyzed to evaluate whether the villagers obtained an adequate harvest to be self-sufficient.

\section{Productivity of the cereals}

In 2007, 84 farmers of four village districts were interviewed to obtain information regarding the harvest of maize and upland rice (Table 1a, b). According to the data, the farmers used rice seeds amounting to $10.4 \mathrm{~kg} /$ acre $(20.0 \mathrm{~kg} / \mathrm{ha})$ and $15.3 \mathrm{~kg} / \mathrm{acre}(33.6 \mathrm{~kg} / \mathrm{ha})$ for sowings in 2005 and 2006, respectively (Table 1a, b).
According to Acland [12], the standard amount of rice seeds used for planting and broadcast sowing in East Africa is $50.6 \mathrm{~kg} /$ acre $(125.0 \mathrm{~kg} / \mathrm{ha})$. In the case of transplantation, this is reduced to $1.7-2.5 \mathrm{~kg} /$ acre $(4.2-6.2 \mathrm{~kg} /$ ha), which is equal to $1 / 30$ or $1 / 20$ of the quantity used for broadcast sowing [12]. Therefore, the number of rice seeds used by the villagers within the study area was close to that generally used for transplanting, even though the villagers in the present study practiced the method of direct sowing.

The average yield of rice in East Africa ranges between 506 and $782 \mathrm{~kg} /$ acre (1250 to $1932 \mathrm{~kg} / \mathrm{ha}$ ) in the case of direct sowing [20], which is significantly less than that in other countries of the region. The yields observed in the study village were at an even lower level, $81.2 \mathrm{~kg} /$ acre $(200.6 \mathrm{~kg} / \mathrm{ha})$ and $83.1 \mathrm{~kg} / \mathrm{acre}(205.2 \mathrm{~kg} / \mathrm{ha})$ in 2005 and 2006, respectively (Table $1 \mathrm{a}, \mathrm{b})$. Under normal conditions of rice cultivation in East Africa, if $110 \mathrm{~kg}$ of seeds are planted in direct sowing, the harvest is $1100-1700 \mathrm{~kg}$, or 10 to 16 times that obtained from sowing seeds [12]. However, in the study village, the harvest was 6.6 and 5.4 times higher, compared to that obtained from direct sowing seeds in 2005 and 2006, respectively. The harvest was 79.0 and $107.2 \mathrm{~kg}$ per household in 2005 and 2006, 
respectively. However, 13 households (15.8\%) did not harvest upland rice at all in 2006. The overall status of the growth of upland rice was poor, and many fields had low yields. In the case of maize, the seeds used for sowing amounted to $5.4 \mathrm{~kg} /$ acre $(13.6 \mathrm{~kg} / \mathrm{ha})$ and $2.1 \mathrm{~kg} /$ acre (5.2 kg/ha) in 2005 and 2006, respectively (Table 1a, b). The average weight of sowing seeds used in East Africa is $25.3-50.6 \mathrm{~kg} /$ acre $(62.5-125.1 \mathrm{~kg} / \mathrm{ha})$ [20]. The average amount of sowing seeds used in East Africa is almost ten times that used in the study village. The seeds used in the present study were sown within an area of $70 \mathrm{~cm} \times 70 \mathrm{~cm}$. Therefore, the area used for planting crops in the study village was comparatively larger than that used in other countries of the region. Therefore, the yield of maize was also significantly smaller. The yield observed was $111.1 \mathrm{~kg} /$ acre $(179.6 \mathrm{~kg} / \mathrm{ha})$ and $120.0 \mathrm{~kg} /$ acre $(242.9 \mathrm{~kg} /$ ha) in 2005 and 2006, respectively (Table 1c, d). The average yield in East Africa is 506-621 kg/acre (1250.7$1534.9 \mathrm{~kg} / \mathrm{ha}$ ) [20], and the yield observed in the study village was nearly one-fifth of that figure. The harvest in the study village was observed to be 35.0 and 16.8 times higher than that obtained from sowing seeds in 2005 and 2006, respectively. The average data for East Africa were generally 10-25 times higher than that observed in the study village. However, the yield per unit area was small, owing to the larger intervals between plantings.

In 2006, harvest failure was observed, even with maize. Despite sowing, five households (6\%) obtained no crops from their fields. This failure occurred because the cultivation was attacked by wild boars and monkeys living in the forest.

\section{Self-sufficiency and consumption of cereals}

The productivity of the main cereals, upland rice and maize, cultivated on the slopes was very low. Furthermore, the production of such crops by many households was also low. This raises the concern about whether the yield of cereals is self-sufficient. The formula introduced by Richards and Widdowson [21] was employed to evaluate the first concern, that is, whether the households under investigation produce sufficient cereals for their own consumption. The number of consumers per household was calculated using the aforementioned formula, and the data are presented in Table 2. Applying this formula, a "consumer" was defined as follows: A man over the age of 15 years was equal to 1 consumer; a woman over the age of 15 years was equal to 0.8 of a consumer; a child between the ages of 7 and 15 years was equal to 0.7 of a consumer; and an infant between the ages of 2 and 7 years was equal to 0.5 of a consumer. The amount of staple food crops needed for daily consumption was calculated using the given index [21]. The average number of consumers per household of 59 households was 2.9
(Table 2). According to our observations, a man over the age of 15 years typically consumes about $250 \mathrm{~g}$ of maize or sorghum flour per meal. Therefore, the estimated average weight of maize flour consumed by a household was $725 \mathrm{~g}(=250 \mathrm{~g} \times 2.9)$ per meal (Table 2$)$.

The annual consumption of rice and maize by each household was estimated using the Richards and Widdowson formula [21] and consumption patterns of household D which the author observed their ordinary lives most frequently (Table 2 ). The consumption of maize was estimated to be $21.8 \%$, according to the consumption patterns of household D. The households under investigation consume maize 238.7 times per year (365 days $\times 3 \times 0.218$ ). Thus, the average consumption of maize per household was $170.3 \mathrm{~kg} /$ household (Table 2). The consumption of rice by household D was $18.7 \%$, and the amount consumed was approximately $250 \mathrm{~g}$. Thus, the estimated rice consumption was $146.1 \mathrm{~kg}$ (Table 2).

A comparison between the consumption and yield of the two main types of cereals is provided in Table 2 . In the case of maize, only nine households out of 59 households $(15.3 \%)$ exhibited a positive value in the calculation of $(\mathrm{Y}-\mathrm{C})$, where $\mathrm{Y}=$ production and $\mathrm{C}=$ consumption (Table 2). The results of the calculation of the remaining 50 households were negative, and the average of 59 households was $-83.8 \mathrm{~kg}$. In particular, the maize deficit in the Ludewa village division was larger than that in the other village divisions. Out of 17 households in the Ludewa village division, six cultivated maize, and the deficit was $141.3 \mathrm{~kg} /$ household. The rice deficit was $49.2 \mathrm{~kg}$ per household, and only 12 households exhibited a surplus. The results show that although some farmers cultivated maize and upland rice on the slopes, production was lower than consumption for many households in the village.

\section{Purchase}

The productivity of maize and upland rice cultivated on the slopes was very low. In addition, the production of cereals was not adequate to achieve self-sufficiency in many households. Therefore, villagers had to purchase food if they wanted to consume cereals throughout the year, as indicated in the consumption patterns of household D (Fig. 2).

Thus, the present study investigated whether the villagers purchased cereals to meet their consumption needs. In 2005, 17 out of 23 households (73.9\%) purchased maize, and 16 out of 23 households (69.6\%) purchased rice (Table 3 ). However, only three out of 23 households purchased cassava (Table 3). According to the interviews conducted among 84 households in 2007, 48 households (57.1\%) regularly purchased either maize or rice, or both (Table 4). 


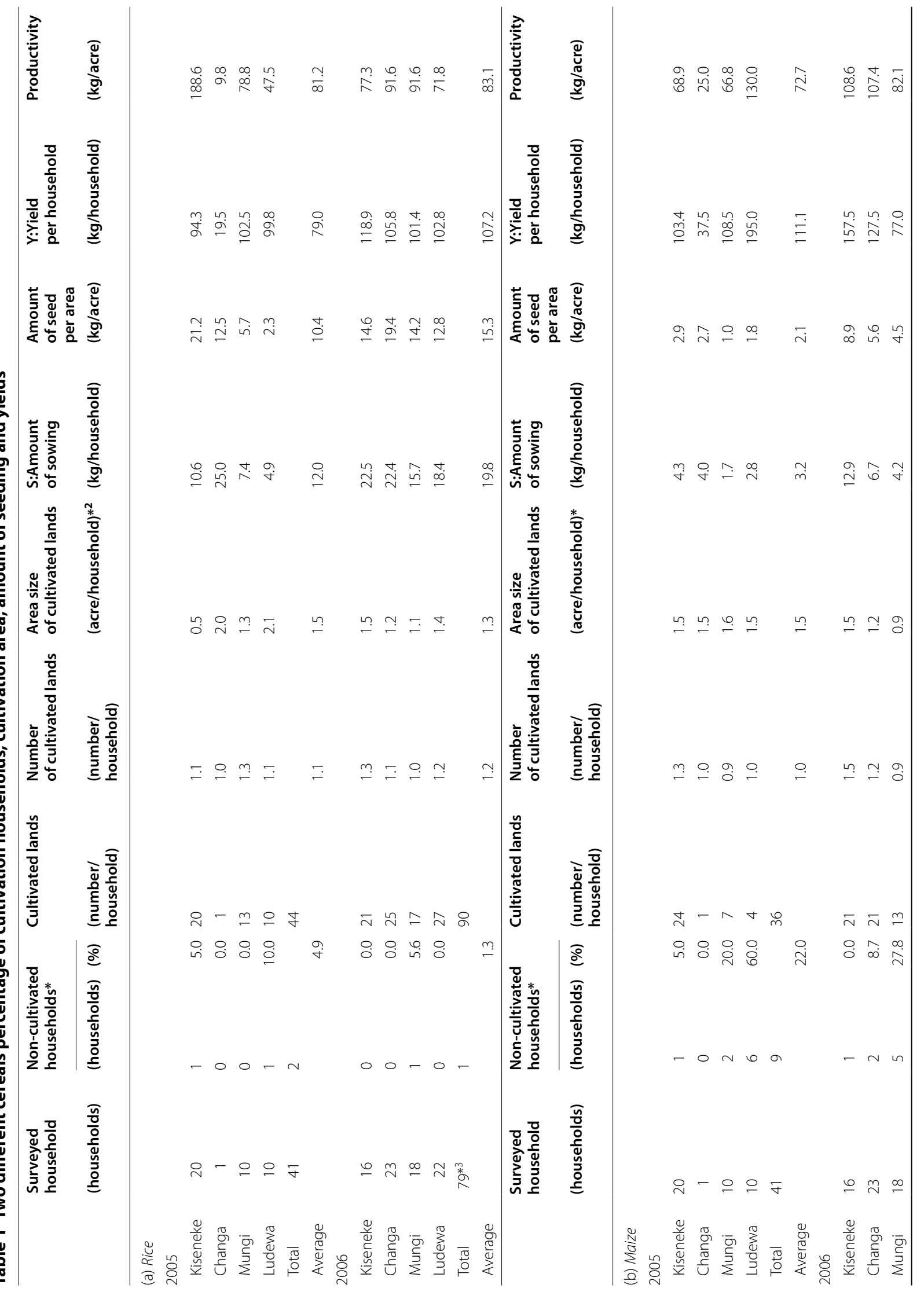




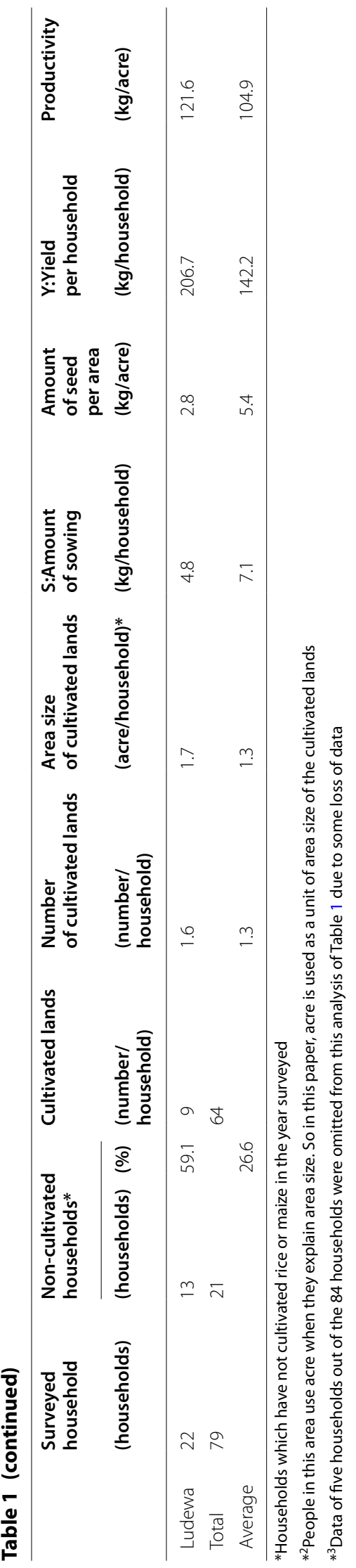




\section{Income generation from staple foods: the role of banana cultivation in home gardens}

Inhabitants of the study area consumed maize and rice throughout the year despite seasonal fluctuations in the consumption rate. The production of these two crops was inadequate for self-sufficiency. Therefore, many households had to purchase rice and maize to compensate for the shortage. Three kiosks in the village sold commodities, such as sugar, soup, maize flour, and rice. The average amount of maize flour sold monthly was $1000 \mathrm{~kg}$ in the largest kiosk and 300 and $200 \mathrm{~kg}$ in the other two kiosks, respectively. Thus, $1500 \mathrm{~kg}$ of maize flour was sold in the village per month. The sale of rice at the largest kiosk and at one of the smaller shops was 500 and $100 \mathrm{~kg}$, respectively. The price of maize was 350-500 TSh (Tanzanian shilling) $/ \mathrm{kg}$ in 2007, a price that is lower than the cost of rice (500-800 TSh $/ \mathrm{kg}$ ). The kiosks did not sell cassava flour, and individual traders managed the cassava business throughout the year at $300 \mathrm{TSh} / \mathrm{kg}$.

The critical question pertained to how the villagers obtained sufficient income to cover food expenses. According to the survey conducted during the present study, $58.3 \%$ of the villagers sold bananas. The highest percentage of banana cultivators $(81 \%)$ was observed in the Kiseneke village division. Banana sales were higher than those of other commercial crops (31.2\%), with the objective of meeting the other food expenses of the villagers (Table 4). In Kiboguwa village, ten commercial crops, including cinnamon, cloves, coconut palm, pineapple, breadfruit, banana, Kidney beans, cardamon, black pepper, coffee were cultivated [10]. The villagers depended mainly on bananas to generate an income to buy daily commodities, despite having different types of commercial crops in their home gardens [10]. Bananas became the main commercial crop of the village. It is presumed that the market was liberalized due to the structural adjustment made by the IMF in 1986 and the cultivation of commercial crops gradually increased in this village. Banana cultivation is assumed more prominent in the study village since the collection place was established in Tawa in the neighboring village in 2004. Since then, banana traders started to visit Tawa to buy the banana from this area. Regardless of the altitude, many villagers plant bananas in home gardens throughout the year [10].

\section{Discussion}

The present study found that villagers achieved food selfsufficiency and had three meals a day with different types of staple foods (Fig. 3a-c). They usually consume ten types of staple food, such as maize, cassava, rice, banana, taro, wheat, breadfruit, yam, sweet potato, and sorghum on a rotation basis and grew nine kinds of them in study village, except the wheat. The major staple food crops were maize, rice, and cassava, and the consumption rate of these foods was generally higher than that of the other staple foods. Most farmers followed the same cropping pattern in primary staple food cultivation. Maize had been cultivated on lands at an altitude of $800 \mathrm{~m}$ above sea level. Upland rice farming was observed in areas below $900 \mathrm{~m}$, and cassava was cultivated at intermediate elevations. The inhabitants of the village divisions at higher attitudes went to the divisions at lower altitudes to cultivate upland rice and cassava. It takes almost one day for a round trip. In contrast, those who lived in village divisions at lower altitudes went to divisions at higher altitudes within a given day to cultivate maize.

The distance from the farmers' homes to the cultivated fields of the staple food crops was generally $>5 \mathrm{~km}$. Therefore, the villagers had to deploy a significant amount of time and labor for the cultivation of the main staple food crops. The productivity of the cereals cultivated on the slopes was poor, self-sufficiency in production was not attained, and some farmers got no yield from cultivation.

Cassava is a crop that converts the greatest amount of solar energy per unit area into soluble carbohydrates; $1 \mathrm{~kg}$ of moisture-free cassava meal yields up to about $3750 \mathrm{kcal}$. Thus, an annual production of 15 tons of cassava meal per hectare would yield 56 million kcal [22]. Cassava had the highest consumption rate among the three main staple food crops. The villagers also recognized that the productivity of cassava per area was comparatively higher, and harvest failure was lower, compared to maize or upland rice.

Some villagers could have obtained sufficient food throughout the year from one acre of cultivated cassava. However, none of the households cultivated only cassava; most tried to cultivate multiple staple food crops, including cereals with low productivity. The villagers continued to have a variety of dietary patterns by changing the staple food crop consumed.

The villagers of Kiboguwa cultivated bananas in home gardens, as a source of both income and food. Bananas are in high demand in the domestic market. Therefore, the price fluctuation of bananas was relatively constant in comparison with the other home garden products, such as clove, cardamom, or cinnamon, all of which are sold in the international market [9]. Thus, bananas represent an important crop for the people of Kiboguwa. The main purpose of banana cultivation for the Haya people [23-25] and the Chaga people [26] are their main staple food, and it is different from the Kiboguwa people.

According to the land tenure system in the study area, to plant perennial crop such as banana or tree crops in the field on the slopes is thought to be difficult. Therefore, many tree crops and banana cultivated in the home 


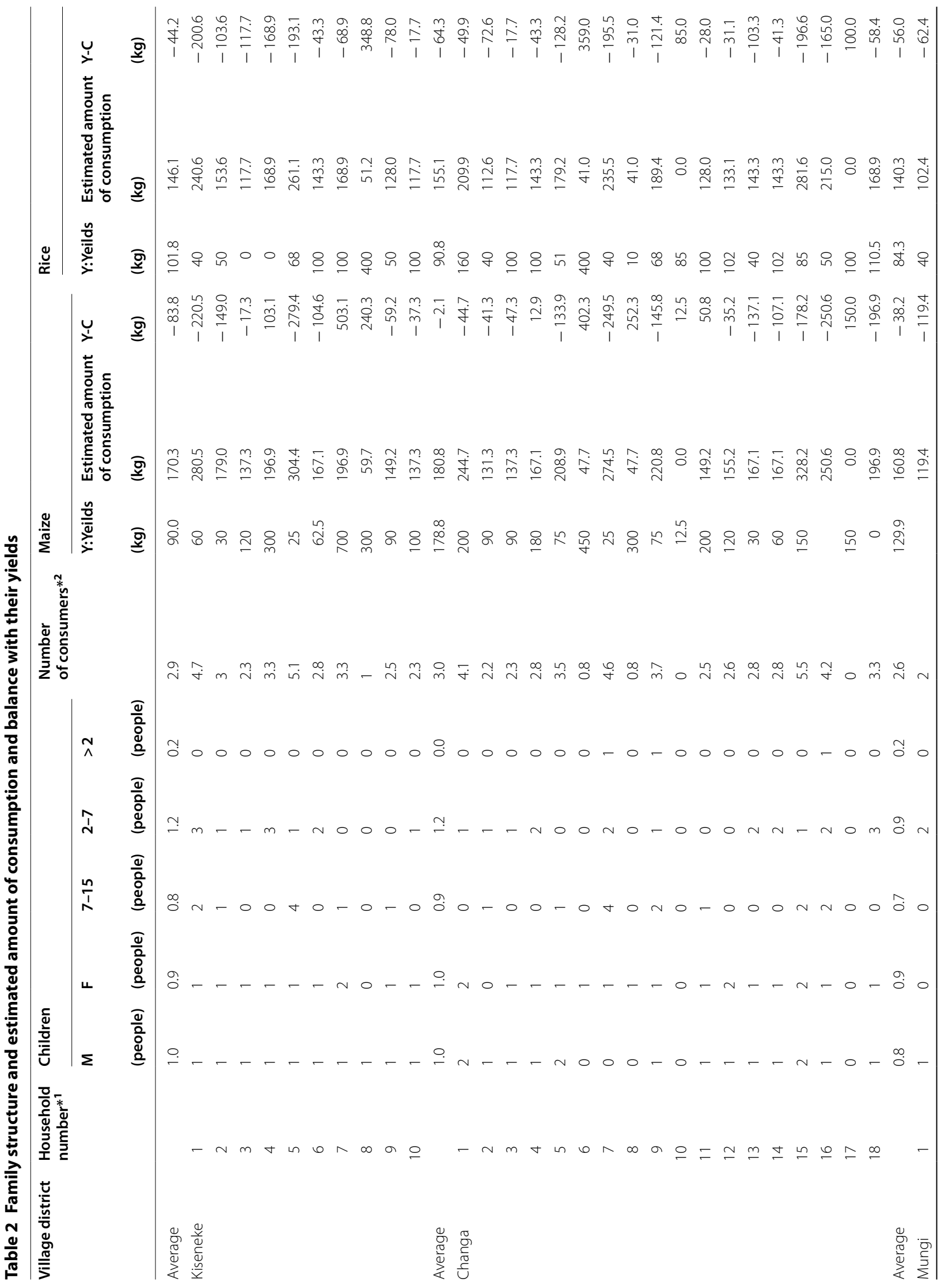




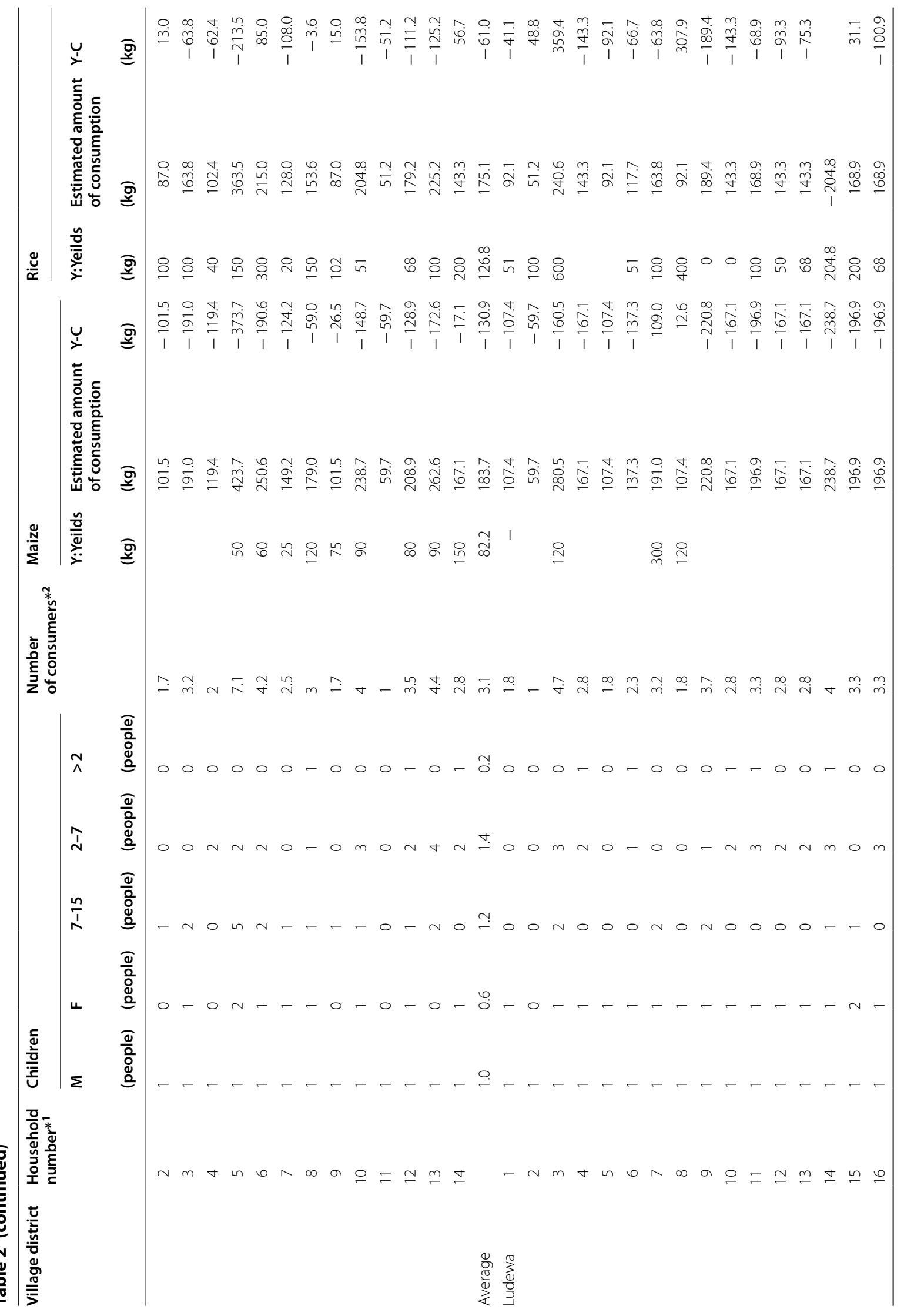




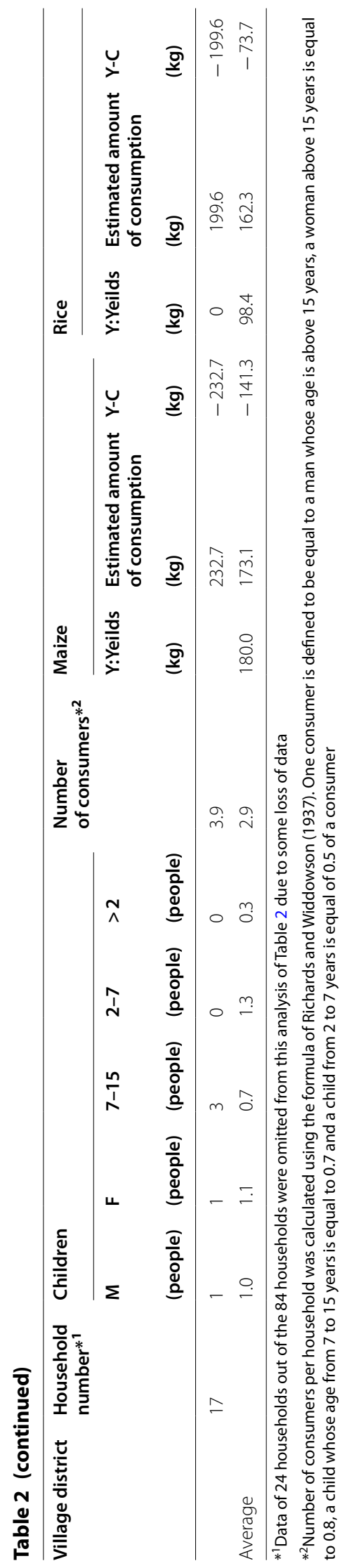


Table 3 Households which purchased foods for their self-consumption in 2006

\begin{tabular}{|c|c|c|c|c|c|c|c|}
\hline \multirow[t]{2}{*}{ Village district } & \multirow[t]{2}{*}{ (household) } & \multicolumn{2}{|l|}{ Maize } & \multicolumn{2}{|l|}{ Rice } & \multicolumn{2}{|l|}{ Cassava } \\
\hline & & (household) & (\%) & (household) & (\%) & (household) & (\%) \\
\hline Ludwig & 5 & 3 & 60.0 & 3 & 60.0 & 0 & 0.0 \\
\hline Mungi & 8 & 5 & 62.5 & 5 & 62.5 & 0 & 0.0 \\
\hline Kiseneke & 10 & 9 & 90.0 & 8 & 80.0 & 3 & 30.0 \\
\hline Total & 23 & 17 & 73.9 & 16 & 69.6 & 3 & 13.0 \\
\hline
\end{tabular}

The members of the households were interviewed to determine whether they constantly purchased each staple food crop

Table 4 The households that purchased a staple food and methods by which they were able to buy in 2007

\begin{tabular}{|c|c|c|c|c|c|c|}
\hline & & Kiseneke & Changa & Mungi & Ludewa & Total \\
\hline Total number of households & (household) & 21 & 23 & 18 & 22 & 84 \\
\hline \multirow[t]{2}{*}{ Households that bought staple food crops* } & (household) & 13 & 13 & 8 & 14 & 48 \\
\hline & $(\%)$ & 61.9 & 56.5 & 44.4 & 63.6 & 57.1 \\
\hline \multicolumn{7}{|l|}{ Agricultural income } \\
\hline \multirow[t]{2}{*}{ Number of households*2 that sold banana } & (household) & 17 & 13 & 8 & 11 & 49 \\
\hline & $(\%)$ & 81.0 & 56.5 & 44.4 & 50.0 & 58.3 \\
\hline \multirow[t]{2}{*}{ Total number of households that sold other crops } & household & 2 & 7 & 5 & 13 & 27 \\
\hline & $(\%)$ & 9.5 & 30.4 & 27.8 & 59.1 & 32.1 \\
\hline Clove & (household) & 1 & 4 & 2 & 4 & 11 \\
\hline Cinnamon & (household) & 1 & 2 & 1 & 4 & 8 \\
\hline Black paper & (household) & 1 & 1 & 1 & 1 & 4 \\
\hline Coco palm & (household) & 0 & 3 & 0 & 3 & 6 \\
\hline Coffee & (household) & 1 & 0 & 1 & 0 & 2 \\
\hline Pineapple & (household) & 0 & 0 & 2 & 1 & 3 \\
\hline Cassava & (household) & 1 & 1 & 1 & 4 & 7 \\
\hline Bread fruit & (household) & 0 & 0 & 0 & 1 & 1 \\
\hline \multicolumn{7}{|l|}{ Non-agricultural income } \\
\hline \multirow[t]{2}{*}{ Total } & (households) & 6 & 10 & 6 & 7 & 29 \\
\hline & $(\%)$ & 28.6 & 43.5 & 33.3 & 31.8 & 34.5 \\
\hline \multirow[t]{2}{*}{ Wedge labor cost } & (household) & 1 & 5 & 3 & 5 & 14 \\
\hline & $(\%)$ & 4.8 & 21.7 & 16.7 & 22.7 & 16.7 \\
\hline \multirow[t]{2}{*}{ Luggage } & (household) & 5 & 5 & 3 & 2 & 15 \\
\hline & (\%) & 23.8 & 21.7 & 16.7 & 9.1 & 26.3 \\
\hline
\end{tabular}

*They were interviewed whether they purchase constantly each staple food crops or not

${ }^{*}$ The household members were asked to indicate their means of earning money when they needed to buy staple food crops in multiple questions

gardens and annual crops such as maize or rice are grown on the fields of the slopes. According to the comparison between the production amount and the consumption amount of cereals which are cultivated on the slopes, we observed that there was a shortage of self-produced cereals. However, the cereal shortage was covered by purchasing them using the profit, which the farmers gain from banana which was grown in home gardens.

Although it might be vital to increase the yield of cassava, it is also essential to secure the dietary supply of the villagers and avoid a sole focus on increasing the yield of cereals. Many studies in modern agriculture have been concerned with the development of technologies that enhance productivity per unit area or achieve a surplus [27]. However, these studies do not adequately take into account the diversity of peoples living in traditional societies or the importance of their cultures [28]. The results of the present study show that rural people in developing countries enjoy their own food culture and are willing to maintain it. Although the original purpose of agriculture is considered to be the development of ethical technology that supports farmers [8]. The current stance adopted by 
developing countries on agricultural research and agricultural development uses a deductive approach to provide the necessary supports [27]. Within the study area, people who transported bananas or performed labor in the context of agriculture, to earn an income to purchase food, were also observed. In moral agricultural development, people who depend on activities related to agriculture for survival must also be taken into account. It is necessary to consider the appropriate and comprehensive means of support for their agricultural activities and livelihoods. This study offers that appropriate support is needed to improve the specific agricultural conditions such as self-sufficiency of farmers and crop cultivation on mountain slopes that lead to soil degrading in rural agriculture in Africa.

\section{Conclusion}

The present study demonstrates the importance of different dimensions of agriculture and staple food crop productivity. It also describes the specific situation of rural farming in Africa. The newly collected information could help policymakers enhance food security in the areas under investigation.

\section{Authors' contributions}

YY conducted data collection and data analysis and was a major contributor in writing the manuscript. All authors read and approved the final manuscript.

\section{Acknowledgements}

Not applicable.

\section{Competing interests}

The authors declare that they have no competing interests.

\section{Availability of data and materials}

All data generated or analyzed during this study are included in this published article [and its supplementary information files].

\section{Consent for publication}

Not applicable.

Ethics approval and consent to participate

Not applicable.

\section{Funding}

This work was supported by Japan Society for the Promotion of Science (JP) Award Number 22710245377.

\section{Publisher's Note}

Springer Nature remains neutral with regard to jurisdictional claims in published maps and institutional affiliations.

Received: 13 February 2018 Accepted: 19 July 2018

Published online: 10 August 2018

\section{References}

1. Angelsen A, Kaimowitz D. Rethinking the causes of deforestation: lessons from economic models. World Bank Res Obs. 1999;14:73-98.
2. Röling N. The agricultural research-technology transfer interface: a knowledge systems perspective. In: Kaimowitz D, editor. Agricultural research and technology transfer in developing countries. Boulder: Westview Press; 1990. p. 1-42.

3. Soda O. Principles of agriculture. Tokyo: Iwanami Shyoten; 2000. p. 312 (in Japanese)

4. Tsuruta T. Historical consideration of agriculture/pastoral complexes in Western African semi arid areas; case examples of the Tanzania ground strip and its surroundings. Bull Fac Agric Kinki Univ. 2011:44:97-114 (in Japanese)

5. Mbaga-Semgalawe Z, Folmer H. Household adoption behavior of improved soil conservation: the case of the North Pare and West Usambara Mountains of Tanzania. Land Use Policy. 2000;17:321-36.

6. Soini E. Land use change patterns and livelihood dynamics on the slopes of Mt. Kilimanjaro, Tanzania. Agric Syst. 2005;85:306-23.

7. Netting RM, Stone MP, Stone GD. Kofyar cash-cropping: choice and change in indigenous agricultural development. Hum Ecol. 1989:17:299-319.

8. Kakeya M. African Area Studies and International Cooperation Native agriculture and regional development. Asian Afr Area Stud. 2001;1:68-80.

9. Lema MA, Majule AE. Impacts of climate change, variability and adaptation strategies on agriculture in semi arid areas of Tanzania: the case of Manyoni District in Singida Region, Tanzania. Afr J Environ Sci Technol. 2009;3:206-18

10. Yamane $Y$, Higuchi $H$. Subsistence strategy of small farmers observed in planting of commercial crops in the homestead of the mountains of rural Tanzania: a case study of Kiboguwa Village on the Eastern Slopes of Uluguru Mountain in Tanzania. J Agric Dev Stud. 2016;27:1-12 (in Japanese)

11. Alcardo A, Barakabitze EJ, Kitindi C, Shabani SA, Philipo J, Kibirige G. New technologies for disseminating and communicating agriculture knowledge and information: challenges for Agricultural Research Institutes in Tanzania. J Inf Syst Dev Ctries. 2015;70:1-22.

12. Mdee A, Wostryb A, Coulsonc A, Marob J. A pathway to inclusive sustainable intensification in agriculture? Assessing evidence on the application of agroecology in Tanzania. Agroecol Sustain Food Secur. 2018. https:// doi.org/10.1080/21683565.2018.1485126.

13. Kimaro DN, Kilasara M, Noah SG, Donald G, Kajiru K, Deckers JS. Characteristics and management of soils located on specific landform units in the northern slopes of Uluguru Mountains, Tanzania. Proc FoA Conf. 1999:4:234-42.

14. Ikeno J, Takeishi M, Rwezimula F, Lubida A, Shirima C, Nkonoki BJ (compil.) 2004 Report of Baseline Survey in Uluguru Mountains: Kibogwa Village \& Tanana Sub-village, Nyachilo Village. (SCSRD, Sokoine University of Agriculture (Tanzania)), unpublished. Masawe, J.L.

15. Rwezimula FN. Participatory rural development approaches for supporting community based activities: case of the Uluguru Mountains, Tanzania thesis to fulfill the requirements for the Degree of Doctor in Global Environmental Studies. Japan: Graduate School of Global Environmental Studies, Kyoto University; 2008. p. 115

16. Young R, Fosbrooke H. Land and politics among the Luguru of Tanganyika. London: Routledge \& Kegan Paul; 1960.

17. Beidelman TO. The matrilineal peoples of eastern Tanzania. London: International African Institute: 1967.

18. Maxwell J. Qualitative research design: an interactive approach (Applied Social Research Methods). London: SAGE Publications; 2005. p. 87-121.

19. Sato Y, Yokoya S. Effects of male sterility caused by low temperature at the booting stage on out-crossing rates in rice (Oryza sativa L.). Breed Sci. 2008;10:127-34 (in Japanese).

20. Acland JD. East African crops: an introduction to the production of field and plantation crops in Kenya, Tanzania and Uganda. London: Longman; 1980

21. Richards Al, Widdowson EM. A dietary study in north-eastern Rhodesia. Africa. 1936;9:166-96.

22. Okezie BO, Kosikowski FV, Markakis P. Cassava as a food. Crit Rev Food Sci Nutr. 1983;17:259-75.

23. Rugalema GH, Okting'ati A, Johnsen FS. The homegarden agroforestry system of Bukoba district, North-Western Tanzania. 1. Farming System Analysis. Agrofor Syst. 1994;26:53-64.

24. Rugalema GH, Johnsen FH, Rugambisa J. The homegarden agroforestry system of Bukoba district, North-Western Tanzania. 2. Constraints to farm productivity. Agrofor Syst. 1994;26:205-14 
25. Maruo S. People who live with bananas. A case study of the village of the Haya in Western Tanzania. In: Kakeya M, editor. African farmer's worldTransformation and its indigenous. Kyoto: Kyoto University Press; 2002. p. 51-90 (in Japanese).

26. Hemp A. The banana of Kilimanjaro: biodiversity and conservation of the Chagga homegardens. Biodivers Conserv. 2006;15:1193-217.
27. Suzuki S. Agricultural extension in developing countries and its evaluation. Tokyo: Tokyo Agricultural University Publishing Association; 2010. p. 230-47 (in Japanese).

28. Soda O. The history of modern agricultural thought—for agriculture in the 21st century. Tokyo: Iwanami Shyoten; 2013. p. 236 (in Japanese).
Ready to submit your research? Choose BMC and benefit from:

- fast, convenient online submission

- thorough peer review by experienced researchers in your field

- rapid publication on acceptance

- support for research data, including large and complex data types

- gold Open Access which fosters wider collaboration and increased citations

- maximum visibility for your research: over $100 \mathrm{M}$ website views per year

At BMC, research is always in progress.

Learn more biomedcentral.com/submissions 